\title{
Anti Corruption Education Through Characters Building Value
}

\author{
Sri Sulistyawati, Risnawaty, Nelvitia Purba \\ Universitas Muslim Nusantara Al-Washliyah Medan
}

\begin{abstract}
Summary
Based on the data reported by Fitra (Indonesian Forum for Budget Transparency) Region Sumatera Utara from the audit results by BPK (Audit Board of the Republic of Indonesia) in the IHP (Summary of Audit Results) for Semester II/2012, North Sumatera Utara is considered as the most corrupted province in Indonesia. It was in the first rank followed by Aceh Province, West Papua Province, and DKI Jakarta in the fourth place.1This anticorruption education is an attempt to build national character as the foundation to prevent corruption conduct. Therefore, early prevention is required through education for senior high school students in North Sumatera Province in order that by the time they get into the employmentwoorld, they will become reliable young generation who will bring Indonesia to achieve just and prosperous society.
\end{abstract}

Keywords: National Character, Senior High School Students, Corruption Prevention, Pakem (Active, Creative, Effective, and Fun Learning Method)-Based.

The objective of this research was:

a. To create an early prevention from corruption in order that a long term Indonesian National Strategy of Corruption Prevention and Eradication, in the period of 2012-2025 will be successful in minimizing corruption in Indonesia in general, and in North Sumatera Province in particular;

b. To getsenior high school students accustomed to anti-corruption as they are in the adolescence phase in which they need a more intensive guidance and direction to become the generation with reliable human resources so that they are able to protect themselves and to be anti-corruption.

c. To build the custom of honesty, discipline, and simple life which are integrated in the subjects given to senior high school students in North Sumatera Province.The objective of the research was to provide information about the model of anti-corruption education that will be implemented to senior high school students in North Sumatera Province by inserting it in all their school subjects. The research method used in this research ${ }^{1}$ was socio-legal research method. ${ }^{2}$ The main problem analyzed and studied in this research was related to "Have the anti-corruption education be immediately implemented on all subjects in senior high schools in North Sumatera Province in particular and in Indonesia in general."

\section{CHAPTER I}

\section{INTRODUCTION}

\subsection{Background}

Corruption has become a central issue in lawenforcement in these decades. Many efforts have been made by the government to eradicate corruption by implementing various national strategies and even more in the reformation era, either through the Presidential Instruction No.5/2004 on Acceleration of Corruption Eradication, Stranas PPK (National Strategy and Action Plan on Corruption Eradication) 2010-2025, the Presidential Instruction No.9/2011 regarding the Plan of Action Acceleration and Corruption Eradication 2011, the Presidential Instruction No.14/2011 on the Plan of Acceleration Action and Corruption Eradication 2012, and the Long Term (2012-2025) and Mid Term (2012-2014)National Strategy of Corruption Prevention and

Eradication. ${ }^{3}$ In the life as a nation and as a state, the cultures of quality, shyness, and work are not yet

\footnotetext{
${ }^{1}$ TiborR.Machan with translator Masri Maris (2006), Freedom and Culture, Jakarta: YayasanOborIndonesia, p.95 stated that understanding the research area condition is very essential to determine the valid and relevant respondents.

${ }^{2}$ Social research on law or what is also called socio-legal research is frequently misunderstood as legal research. It is all because socio-legal research and legal research have the same object, namely law. However, a socio-legal research merely views law as a social sign. Such researches stress on individual and social behavior in relation to law (see further Peter Mahmud Marzuki, Legal Research, Prenada Media Group.2011, page 87)

${ }^{3}$ Marwan Effendy, Corruption and National Strategy of Its Prevention and Eradication, Referensi Press Group, 2013, page 2Data Analysis 
built either among the leaders or the people in general, so that it is difficult to find a figure to be followed. This is a proof that there has been a shift of values toward chaos or the emergence of new values on the basis of pragmatism, materialism, hedonism, secularism, and even atheism. This sad condition and reality have brought about many questions from various parties, either in the society in general or among the education experts. "What is wrong with the national education so that Indonesian people have not yet developed to be what is determined in Pancasila (National Ideology), the 1945 Constitution, and the Law on National Education System?'Based on the above explanation, the government has designed the Curriculum 2013 in which the topics are taught to senior high school students through interdisciplinary of various fields of subject. The objectives of this curriculum are able to stimulate logic, to challenge the students find themselves the answers to the problems of daily life with national characters.

The character of a nation is the identity, value, and norm of life which become the foundation of nation's thinking and action. The character of a nation is also the reflection of the individuals of the nation.

Building national character takes a long time because national character is the nation's civilization. In the peak of the celebration of the National Education Day held in Istana Negara on May 11, 2010, President SusiloBambangYudhoyono delivered his speech concerning the character building of Indonesia. He said that, "Character Building has been getting forgotten, the characters of Indonesia has begun to be forgotten by the education world. This is proven by the littlenational noble values ${ }^{4}$ oriented in the curriculum of education.

The objective of the learning of anti-corruption education to senior high school students is to increase their sensibility of national culture, to give soul satisfaction, and to enrich the esthetical strength through language; and literature appreciation is the learning to an understanding of humanity values in literature that can be related to the relevant condition of the society. In an effort to help preventing the crime in North Sumateraconsidering religious ethics and the legal apparatus is considered failed in organizing the nation as the big number of crime gives impact on the future of humankind, particularly in the youth generation, through interdisciplinary learning by inserting anti-corruption education to senior high school students that can be an alternative way to rebuild today'sunfavorable condition. ${ }^{5}$

National character building is the foundation for crime prevention that will be early implemented to the students in North Sumatera so that by the time they get into employment world, they will become reliable young generation who are anti-corruption in order that Indonesia will achieve just and prosperous society.

\subsection{Problem Statement}

How is the model of interdisciplinary learning for every subject to the senior high school students particularly in North Sumatera Province and in Indonesia in general in order to prevent corruption which is a part of the national strategy of Corruption Prevention in Indonesia until 2025?

\section{Chapter.II \\ II. Method of Reseach}

This research used Research and Development and sosiological research approach. The population are teachers in Sumatera Utara and the sample are taken from 5 district by purposive sampling. Prime rerource data are taken from the teacher. Secondari data are taken from the library, law, documen. The data ara also taken by observation, Questioner, interview and document studied. The data were analysis by tabulation the data.

Data Analysis

Analysis performed in the first Phase I study is a qualitative descriptive. The methods used are intended to get the picture clearly and appropriately with the goal penelitian.Dari the analysis of data provided and designed in mind with an anti-corruption education learning model is effective for early prevention of corruption in North Sumatra.

\section{Chapter.III}

III.Discussion

Analysis performed in the first Phase I study is a qualitative descriptive. The methods used are intended to get the picture clearly and appropriately with the goal penelitian.Dari the analysis of data provided and designed in mind with an anti-corruption education learning model is effective for early prevention of corruption in North Sumatra.

${ }^{4}$ PujoWidodo, Education of National Character through Literature Learning, FKIP Univ.Terbuka. 2010. ${ }^{5}$ http:publiksastra.net/penanaman-budi-pekerti-melalui-pembelajaran-sastra, accessed on October 7, 2013.

DOI: 10.9790/0837-2201020711 $\quad$ www.iosrjournals.org $\quad 8 \mid$ Page


Pakem (active, creative, effective, and Fun) Learning Model to Senior High School Students for Corruption Prevention in Sumatera Utara

Pursuant to the National Policy of Nation's Characters Building (2010), the Ministry of National Education has made the Main Design of Character Education (2010). The Theme of the National Character Building and Character Education was:Buildingthe honest smart, tough, and caring generation. ${ }^{6}$ Character Education in an education unit includes learning in the classroom, daily activities at school, and co-curricular and extracurricular activities. Character education in a formal education unit needs to be supported by daily activities at home (culture at home).

National policy on National Character Building 2010-2025 stated that

An education unit is the media of students' character training and development conducted formally at school. It is empowered through

a. Regulating the integration of character learning in all subjects;

b. Improving school capacity as the media of character education through trainings for teachers;

c. Supplying relevant learning resources in effort to develop students' characters;

d. Awarding an education unit that succeeds in developing character culture. ${ }^{7}$

Before making the learning model to senior high school students in order to prevent Corruption Criminal Conduct, a learning strategy model that contains characters in general will be proposed.

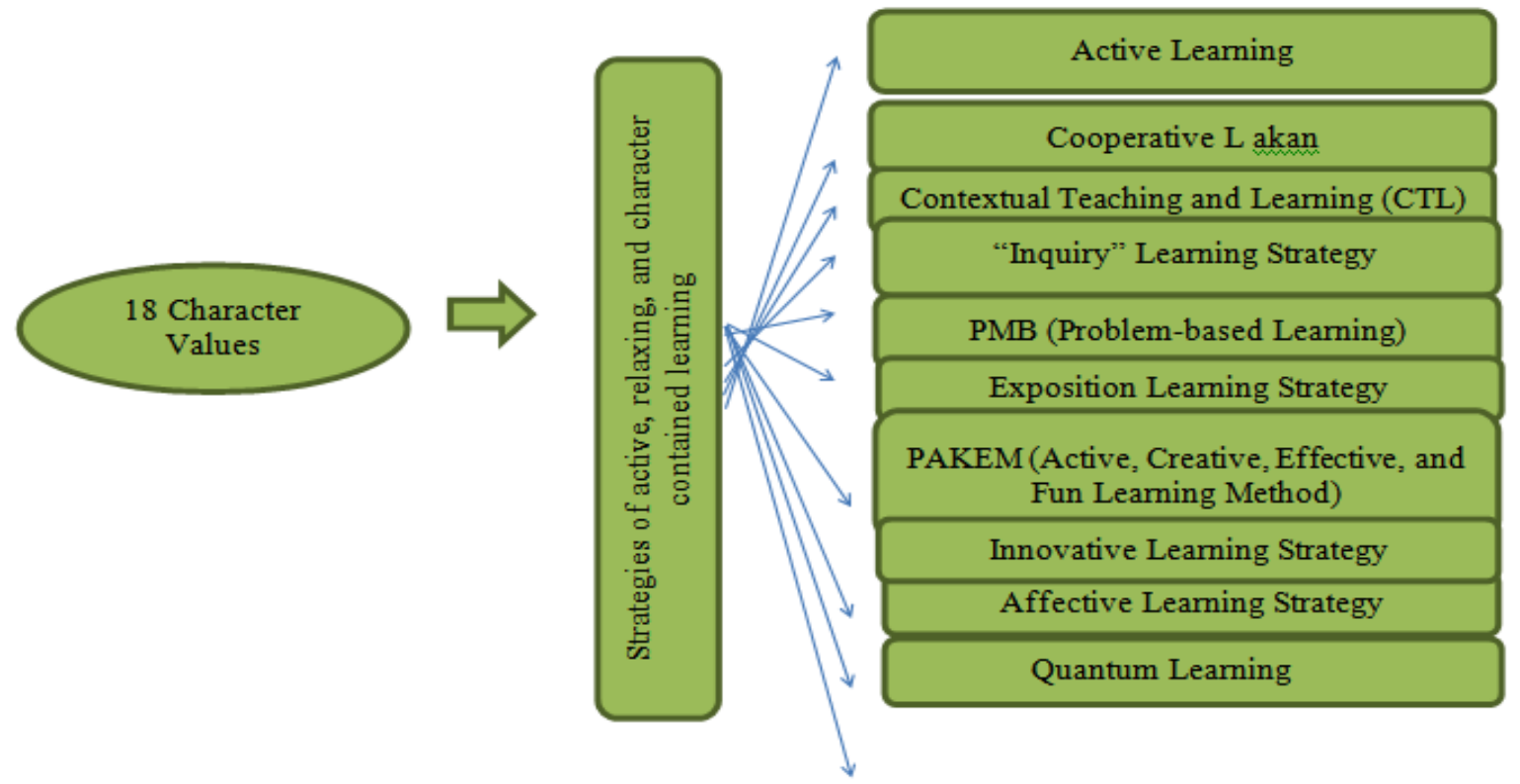

Picture 1 Model of active, fun, and character-contained Learning Strategy

According to the data obtained by the researcher in the field, there were 5 districts, namely:

1. Medan

2. Langkat

3. PematangSiantar

4. Labura

5. LabuhanBatuInduk

Then the researcher took data from three districts, namely:

1. Medan

2. Langkat Regency

3. PematangSiantar

4. Labura Regency

5. LabuhanBatuInduk Regency

Furthermore, the schools selected as the samples were:

Medan.

1. SMK Pempropsu Medan

${ }^{6}$ DamiyatiZuchdi, Zuhdan Kun Prasetya, MuhsinatunSiasahMasruri, Model of Character Education, Integrated in School Cultural Learning and Development, National Library, 2013, page 25.

${ }^{7}$ DamiyatiZuhdi, Zuhdan Kun Prasetya, MuhsinatunMasruri, the Model of Character Education, 2013, page 26.

DOI: 10.9790/0837-2201020711 www.iosrjournals.org $9 \mid$ Page


2. SMK SekolahBinaan (Fostered School) of UMN Al Washliyah) Medan

3. AliyahMualiminProyekUniva Medan

\section{PematangSiantar}

1. SMA Neg 4 PematangSiantar

2. SMA Neg.5 PematangSiantar

3. SMAS KartikaPematangSiantar

Langkat

1. SMAN 1 Gebang

2. SMAN 1 TanjungPura

3. SMAN 1 Stabat

Labuhan Batu Utara

Kabupaten Labuhan Batu Utara

1.SMA Negeri I Kualuh Selatan

2.SMA Swasta Muhamadiyah - 9 Kualauh Hulu

3.SMA Negeri I Kualau Hulu

Kabupaten Labuhan Batu Induk.

1.SMA Negeri I Rantau Selatan

2.SMA Kemala Bayangkari II Rantau Prapat.

The sample selection has been accomplished in the 5 districts. Basically, the teachers taken as the respondents in this research were aware of the definition of Corruption Crime Conduct, 90 out of 100 respondents $(90 \%)$ defined corruption as the action conducted by an individual or a group of people for their own sake, so that it harms country's money or causes loss that does not suit the needs.Moreover, 95 respondents (95\%) who had been given questionnaires and interviewed stated that they agreed that corruption harmed the people so that moral values such as anti-corruption and shy cultures needed to be planted to senior high school students as an effort to prevent anti-corruption and it was also necessary to include learning material about corruption and its impact on students inall subjects in SMA (Senior High School).This was in line with what Suyadi proposed that 18 character values could be applied in the learning process in all school subjects, either in the IPA Group (mathematics, physics, chemistry, etc.) or the IPS Group (language and literature, art, religion, and other subjects).

According to the Learning Model proposed by Suyadi, there are 10 models of active, fun, charactercontained learning strategyas showed in Picture 1.

Pakem Learning Model is the model that has just been applied in the learning of corruption criminal act. PAKEM is an abbreviation of active, creative, effective, and fun Learning. It is the learning model implemented in the curriculum and made perfect under the supervision of MBE (Managing Based of Education)) from UNESCO, in its implementation it developed the critical, creative and problem solving ability. ${ }^{8}$

Pakem Model is a learning model desired in the implementation of KSTP (An Education Unit Curriculum) in the classrooms as it is one of the KTSP development pillars besides school management and PSM (Society participation role).

The curriculum 2013 was designed to prepare Indonesian generation with life capabilities as an individual and citizen who are productive, creative, innovative, and affective as well as are capable of giving contribution to the people, country, nation, and world civilization. The implementation of Curriculum 2013 was:

Emphasis on process and result-base

Honesty, hard work, and discipline are not absent from the assessment process;

The research results had to be harmonious with students' character and moral development as an individual, social, citizen, and a creature of God the Almighty.

It is clear now, based on the above description, that Pakem method has been arranged in the Curriculum 2013, but in its implementation it has not yet been implemented as it should be.

Pakem is also the learning approach that enables the students to do various activities in order to develop their skills, behavior, and understanding by emphasizing on the learning while working, whereas teachers used various resources and learning media including the involvement of the environment to make learning more interesting, fun, and effective.

\section{Chapter.IV \\ IV.CONCLUSION}


Pakem Model is a learning model desired in the implementation of KSTP (An Education Unit Curriculum) in the classrooms as it is one of the KTSP development pillars besides school management and PSM (Society participation role). The curriculum 2013 was designed to prepare Indonesian generation with life capabilities as an individual and citizen who are productive, creative, innovative, and affective as well as are capable of giving contribution to the people, country, nation, and world civilization. The implementation of Curriculum 2013 was:

Emphasis on process and result-base

Honesty, hard work, and discipline are not absent from the assessment process;

The research results had to be harmonious with students' character and moral development as an individual, social, citizen, and a creature of God the Almighty. It is clear now, based on the above description, that Pakem method has been arranged in the Curriculum 2013, but in its implementation it has not yet been implemented as it should be. Pakem is also the learning approach that enables the students to do various activities in order to develop their skills, behavior, and understanding by emphasizing on the learning while working, whereas teachers used various resources and learning media including the involvement of the environment to make learning more interesting, fun, and effective.

\section{REFERENCE}

[1] Ahimsa Putra, H.S.2003, Jurnal Wacana : Korupsi Di Indonesia : Budaya Atau Politik Makna?, Yogyakarta , Insist Press.

[2] Aziz Syamsuddin, 2011, Tindak Pidana Khusus, Sinar Grafika Jakarta.

[3] Bibit Samad Rianto, 2009, Undang-Undang Pengadilan Tipikor Dan Eksistensi Komisi Pemberantasan Korupsi, dalam Amir Syarifudin, dkk (penyunting) Bunga Rampai Potret Penegakan Hukum di Indonesia, Jakarta : Komisi Yudisial Republik Indonesia.

[4] Ermanjah Djaja, 2010, Meredesain Pengadilan Tindak Pidana Korupsi (Implikasi Putusan Mahkamah Konstitusi Nomor 012-016019/PPU-IV/2006), Sinar Grafika Jakarta.

[5] Ermansjah Djaja, 2009, Membrantas Korupsi Bersama KPK

[6] Evi Hartanti, 2012, Tindak Pidana Korupsi, Edisi Ke dua, Jakarta, Sinar Grafika

[7] Hamzah Andi, 1991, Korupsi di Indonesia Masalah Dan Pemecahannya, Jakarta: PT Gramedia.

[8] Handoyo Eko, 2009, Pendidikan Anti Korupsi, Semarang : Widyakarya Press.

[9] ICW, 2000, Peran Parlemen Dalam Membasmi Korupsi, Jakarta ; ICW.

[10] Juniver Girsang,2012, Abuse Power (Penyalahgunaan Kekuasaan Aparat Penegak Hukum Dalam Penanganan Tindak Pidana Korupsi), JG Publishing.

[11] Kaelan Dan Achmad Zubaidi, 2007, Pendidikan kewarganegaraan Untuk Perguruan Tinggi, Paradigma Yogyakarta.

[12] Lexy Moleong, 2005, Metodologi Penelitian Kualitatif,PT.Remaja Rosdakarya Bandung.

[13] Marwan Effendy, 2011, Kapita Selecta Hukum Pidana (Perkembangan Dan Isu-Isu Aktual Dalam Kejahatan Finansial Dan Korupsi), Referensi Jakarta.

[14] Martiman Prodjohamidjojo, 2001, Penerapan Pembuktian Terbalik Di Dalam Delik Korupsi, Mandar Maju Bandung

[15] Peter Mahmud Marzuki,2011, Penelitian Hukum, Kencana Prenada Media Group Jakarta.

[16] Satjipto Rahardjo,1983,Hukum Dan Perubahan Sosial Suatu Tinjauan Teoritis Serta Pengalaman-Pengalaman Di Indonesia, Alumni Bandung.

[17] Sulistyantoro, HT, 2004, Etika Kristen Dalam Menyikapi Korupsi, Kompas, Senin, 2 Agustus 2004.

[18] Syaiful Bakhri, 2009, Pidana Denda Dan Korupsi, Total Media Jakarta.

[19] Sudarsono, 2007, Kamus Hukum, Rineka Cipta Jakarta.

[20] Syahrial,Aliaras Wahid, H.A Djasli,Sugeng Wibowo, 2006, Membangun Karakter Dan Kepribadian Melalui Pendidikan Kewarganegaraan, University Press jakarta.

[21] Peraturan Perundang-undangan :

[22] Undang-Undang Dasar Tahun 1945 Hasil Amandemen.

[23] Undang-undang Republik Indonesia Tentang Tindak Pidana Korupsi Nomor 31 Tahun 1999 Jo Undang-Undang Republik Indonesia Nomor 20 Tahun 2001.

[24] Undang-Undang Republik Indonesia Nomor 30 Tahun 2002 Tentang Komisi Pemberantasan Tindak Pidana Korupsi.

[25] Undang-Undang Republik Indonesia Nomor 12 Tahun 2006 Tentang Kewarganegaraan Republik Indonesia

[26] Kepmendiknas Nomor 232/U/2000 Tentang Pedoman Penyusunan Kurikulum Pendidikan Tinggi Dan Penilaian Hasil Belajar Siswa.

[27] Kepmendiknas Nomor 45/U/2002 Tentang Kurikulum Inti Pendidikan Tinggi

[28] Kep Ditjen Depdiknas Nomor 43/DIKTI/2006 Tentang Rambu-Rambu Pelaksanaan Kelompok Mata Kuliah Pengembangan Kepribadian Di Perguruan Tinggi

[29] Surat Edaran Dirjen DIKTI Tentang Implementasi Pendidikan Anti Korupsi Di perguruan Tinggi.

[30] Httml//:file://Penerapan Pembelajaran Problem Based Learning diakses pada tanggal 22 Pebruari 2013.

[31] 2.mhtml:file//E//mujtahid.upaya melawan korupsi.mht.diakses pada tanggal 18 Pebruari 2013.

[32] http://id.wikipedia.org/wiki-korupsi-diIndonesia.diakses pada tanggal 21/2/2013.

[33] http://kagalimurshid.blogspot.com/2007/05/pendidikan-anti-korupsi-berbasis-html.diakses pada tanggal 22 Pebruari 2013.

[34] mhtml:file://E// dunia Pendidikan Sebagai tumpuan Harapan Untuk Mencegah Korupsi.Diakses pada tanggal 22 Pebruari 2013.

[35] http://id.wikipedia.org/wiki/komisi-pemberantasan-korupsi, diakses pada tanggal 21 Pebruari 2013.

[36] http;//www.theocrowdvoice.com/post/kejahatan-kerah-putih-collar-crime-html.

[37] http://www.slideshare.net/earfullah/akar-masalah-korupsi-dan-pemberantasannya.diakses pada tanggal 22 Pebruari 2013.

[38] http://hukum-kompasiana-com/2012/07/peran-strategis-perguruan-tinggi-dalam-pemberantasan-korupsi, diakses pada tanggal 22 Pebruari 2013.

[39] Mhtml;//E://Usaha Tiongkok Pemberantasan Korupsi/jurnal Toddupuli.mht.diakses pada tanggal 22 Pebruari 2013.

[40] http://wahid-biyole.blogspot.com/2012/09/hukum-fenomena-kebobrokan-korupsi-html.diakses pada tanggal 23 Pebruari 2013.www.google.co.id 